\title{
Mental health, natural and human-made disasters: lessons learnt and future needs
}

\section{F. Amaddeo*, Guest Editor and M. Tansella, Editor}

In the medical literature, the interest in what happens before, during and after natural or human-made disasters is growing. Disasters and large-scale crises continue to increase in frequency. During the last quarter century, more than 3.4 million lives have been lost due to disasters and tens of billions of dollars spent on repairing damage and reconstructing lives (Hogan \& Burstein, 2007).

Natural disasters like earthquakes, landslides, volcanic eruptions, floods and cyclones kill thousands of people and destroy billions of dollars of habitats and properties each year. The rapid growth of the world's population and its increased concentration, often in hazardous environments, has escalated both the frequency and the severity of natural disasters. Although it may not be possible to control the nature and to stop the development of natural phenomena, efforts could be made to avoid disasters and alleviate their effects on human lives, infrastructures and properties.

On the other side, human-made disasters are those disasters resulting from human-made hazards. We can distinguish sociological hazards like wars, terrorism, civil disorders, arsons from technological and/or industrial hazards like mining accidents, structural collapses, environmental and contamination hazards (e.g., nuclear hazards).

If we look specifically at mental health, we see that a wide literature exists on the psychological effects of natural and human-made disasters (e.g., PostTraumatic Stress Disorders (PTSD), anxiety disorders, etc.), while very little has been studied about the effects of disasters on functioning and organization of mental health services and on the long-term effects on the prevalence of mental disorders.

A wide review of disaster-specific literature published from 1977 to 2009 (Smith et al. 2009) showed that following 25 individual disasters or overwhelming crises, a total of 2098 peer-reviewed, event-specific publications were published in 789 journals (652 publications following disasters/events caused by natural

* Address for correspondence: Professor Francesco Amaddeo, Department of Public Health and Community Medicine, Section of Psychiatry and Clinical Psychology, Ospedale Policlinico 'G.B. Rossi', Piazzale L.A. Scuro 10, 37134 Verona, Italy.

(E-mail: francesco.amaddeo@univr) hazards, 966 following human-made/technological disasters/events and 480 following conflict/complex humanitarian events). The event with the greatest number of peer-reviewed, event-specific publications was the 11 September 2001 terrorist attacks (686 publications). Human-made/technological events tend to result in a greater number of psychosocial studies and peer-reviewed publications (with an emphasis on post-traumatic stress disorder and mental health), whereas disasters due to natural hazards and conflict events predominantly result in publications on medical/health-related response to the event.

Most studies that provide information on mental health services use the following disasters that have been limited to examining the rates of services utilization in victims, but not in those patients with previous contacts with mental health services. Services utilization studies can be then divided into either those that examine mental health services use among the direct victims or those that examine mental health services use in the affected community (Rodriguez \& Kohn, 2008).

In a survey (Wang et al. 2007) of 1043 survivors of Hurricane Katrina, 16\% had sought mental health services: $4 \%$ sought a mental health specialist and $11 \%$ a general medical provider. Only $18 \%$ of those with a new-onset disorder sought treatment. Psychopharmacological treatments were used by $12 \%$ of the sample, $19 \%$ with a mild to moderate mental illness and $37 \%$ with a severe mental illness. The most commonly prescribed psychopharmacological agents were antidepressants, followed by benzodiazepines; psychotherapy was utilized by $16 \%$. Of those who did receive psychotherapy following the disaster, $60 \%$ had dropped out of treatment. Fourteen percent of the respondents who did not seek treatment reported that they were in need of treatment. In a subsequent study conducted among people with preexisting mental disorders who reported using mental health services in the year before the hurricane, over one-fifth experienced reduction in or termination of treatment after Hurricane Katrina (Wang et al. 2008).

Jones et al. (2009), for example, showed that people with severe mental disorders are a neglected and vulnerable group in complex emergencies and they stated that protection and care of people with severe mental disorders in complex emergencies is a humanitarian responsibility. 
To mitigate the potential catastrophes that humanity is facing in the new millennium, an evidence-based approach to disaster management is urgently required (Smith et al. 2009).

In this issue of Epidemiology and Psychiatric Sciences, we publish three Editorials and one Special Article on this topic. The first Editorial is written by Yuriko Suzuki and Yoshihari Kim (Suzuki \& Kim 2012) from the National Institute of Mental Health in Tokyo (Japan). The authors analyse the countermeasures that have been taken after the triple disaster of earthquake, tsunami and atomic power plant accident occurred on 11 March 2011. In the first phase, an initial response was taken to assure the continuation of previous psychiatric services and the supply of necessary medical drugs, as well as the treatment of acute mental disorders such as panic, delirium or acute stress reactions. Mental health teams were dispatched to the affected areas, based on previous experiences after the Hanshin-Awaji and Niigata earthquakes in 1995 and 2004, respectively. These teams comprised psychiatrists, nurses, psychologists and/or case workers, many of whom initially travelled in land cruisers, equipped to be self-sufficient and self-supporting, and to provide medication and services for psychiatric outpatients whose treatment had been interrupted. Provision of information was enormously important after the disaster to avoid confusion, not only among those affected but also among care providers. Six months after the earthquake, the problems currently being assessed are those related to prolonged reactions, which go beyond the level of a normal reaction, and more complex forms of disaster-related problems in addition to pre-existing ones.

The second Editorial, written by Casacchia et al. (2012) from the University of L'Aquila (Italy), reports the direct experience of the authors as disaster survivors and professionals of the psychiatric services in L'Aquila after the earthquake occurred on 6 April 2009. The earthquake left 66000 people displaced. Approximately 44000 found an accommodation in tented camps close to their place of residence, and a further 20000 were housed in hotels on the Abruzzo Adriatic Sea coast. Others stayed with friends and relatives throughout Italy.

Working directly on the ground, the authors explain to us the results of the studies conducted to evaluate the consequences of the disaster and the possible strategies to deal with them. For example, among patients with a previous diagnosis of schizophrenia who were admitted to the acute psychiatric ward, 15\% met the DSM-IV criteria for PTSD and showed a more severe positive symptomatology and a statistical significant impairment on working memory compared to the subgroup of schizophrenic patients not showing PTSD (Pollice et al. 2010).
Information about the Project 'Programma di Supporto Psicosociale Emergenza Sisma', SPES, (Psychosocial Support and Earthquake Emergency) is also given in the Editorial. The project was carried out in a tent. It was approved in May 2009 and granted by the Italian Minister of Health. Still ongoing, the project includes three main areas of intervention: (1) assessment of the earthquake impact on the general population; (2) cooperation with general practitioners in order to improve their skills in the identification and psychological management of traumatic events; (3) support of mental health services in the Region in order to learn specific Evidence-Based Medicine (EBM) treatments for PTSD disorders and offer a broader range of EBM treatments to survivors.

The third Editorial is written by Lloyd I. Sederer (2012) and analyses the differences between natural and human-made disasters. Although there is no consensus of opinion in the scientific world, it seems that human-made disasters have more severe clinical impairments and worse outcomes than natural disasters. It is interesting to notice that human-made disasters tend to have no limits: they do not come and then go, like a hurricane or fire or flood. Their menace persists, since the perpetrators are all around us. Our world becomes one of unpredictability and peril. The author concludes that when disaster and trauma are human made then the bedrock of trust in others and in the community is challenged and readily damaged.

In this issue of Epidemiology and Psychiatric Sciences, we also publish a Special Article written by Kessler et al. (2012) on 'The importance of secondary trauma exposure for post-disaster mental disorder'. The authors report the results of the WHO World Mental Health (WMH) Surveys that show clearly that a substantial proportion of people in the $\mathrm{WMH}$ countries have been exposed to natural disasters that a meaningful proportion of these people experience secondary disaster-related traumas (e.g., death of a loved one and destruction of property) and that the significant associations of disaster exposure with anxiety-mood disorders are due to these secondary stressors. The importance of secondary stressors complicates the already challenging public health problem of estimating need for treatment of mental disorders in disaster settings.

The three Editorials and the Special Article give to EPS readers a comprehensive view of the challenges for epidemiological studies in this field. Mental health services should be prepared to react against the consequences of natural and human-made disasters and this capacity should be supported by scientific evidence. We also have to consider that quite often natural disasters are combined with human-made catastrophic consequences due to deforestation, unplanned growth 
proliferation of non-engineered constructions, tardy communication, poor or no budgetary allocation for disaster preventing strategies. For these reasons, natural disasters as well as human-made ones could also produce, along with other secondary traumas, the lack of trust in others and in the community.

\section{Salute mentale, disastri naturali e provocati dall'uomo: lezioni apprese e bisogni futuri}

Nella letteratura medica, l'interesse per ciò che accade prima, durante e dopo disastri naturali o provocati dall'uomo sta crescendo. Disastri e grandi crisi continuano ad aumentare di frequenza. Durante l'ultimo quarto di secolo, più di 3.4 milioni di vite sono state perse a causa di disastri e decine di miliardi di dollari spesi per riparare i danni e ricostruire (Hogan \& Burstain, 2007).

Disastri naturali come terremoti, frane, eruzioni vulcaniche, inondazioni e cicloni sono i rischi naturali che uccidono ogni anno migliaia di persone e distruggono miliardi di dollari di habitat e di proprietà. La rapida crescita della popolazione mondiale e la sua maggiore concentrazione, spesso in ambienti pericolosi, ha aumentato sia la frequenza sia la gravità dei disastri naturali. Anche se potrebbe non essere possibile controllare la natura e bloccare lo sviluppo dei fenomeni naturali, sarebbe invece possibile impegnarsi per evitare i disastri e alleviare i loro effetti sulle vite umane, sulle infrastrutture e sulle proprietà.

Al contrario, disastri provocati dall'uomo sono quelle catastrofi dovute a pericoli messi in atto dall'uomo. Possiamo distinguere i rischi sociologici come le guerre, il terrorismo, disordini civili, incendi dolosi dai rischi tecnologici e/o industriali, come incidenti minerari, crolli strutturali, rischi ambientali e contaminazione (ad esempio, i rischi nucleari).

Se guardiamo in particolare alla salute mentale, vediamo che esiste un'ampia letteratura sugli effetti psicologici di disastri naturali e umani (per esempio, PTSD, disturbi d'ansia, ecc.), mentre molto poco è disponibile sugli effetti dei disastri sul funzionamento e l'organizzazione dei servizi di salute mentale e sugli effetti a lungo termine sulla prevalenza dei disturbi mentali.

Un'ampia revisione della letteratura specifica dei disastri pubblicata tra il 1977 ed il 2009 (Smith et al. 2009) ha mostrato che, seguendo 25 disastri o importanti crisi, un totale di 2.098 pubblicazioni peerreviewed che si occupavano di eventi specifici sono state pubblicate in 789 riviste (652 pubblicazioni a seguito di eventi causati da calamità naturali, 966 disastri provocati dall'uomo o tecnologici, e 480 su conflitti o complessi eventi umanitari). L'evento con il maggior numero di peer-reviewed, eventi specifici pubblicazioni è stato quello dell'11 settembre 2001 con gli attacchi terroristici (686 pubblicazioni). Gli eventi provocati dall'uomo hanno prodotto un maggior numero di studi psico-sociali e pubblicazioni peerreviewed (con l'accento sul disturbo post-traumatico da stress e sulla salute mentale), mentre le catastrofi naturali e gli eventi di conflitto hanno prevalentemente prodotto pubblicazioni sulla risposta medico/sanitaria all'evento.

La maggior parte degli studi che forniscono informazioni sull'utilizzazione dei servizi di salute mentale in seguito a disastri si sono limitati ad esaminare i tassi di utilizzazione nelle vittime, ma non tra coloro che precedentemente utilizzavano i servizi di salute mentale. Gli studi di utilizzazione dei servizi possono essere quindi divisi in quelli che esaminano l'uso dei servizi di salute mentale tra le vittime dirette e quelli che esaminano l'uso dei servizi di salute mentale nella comunità colpita (Rodriguez \& Kohn, 2008).

In uno studio (Wang et al. 2007) su 1043 sopravvissuti all'uragano Katrina, è riportato che il 16\% si era rivolto ai servizi di salute mentale: il $4 \%$ ha cercato uno specialista della salute mentale e $\mathrm{l}^{\prime} 11 \%$ un medico di medicina generale. Solo il $18 \%$ di quelli con un disturbo di nuova insorgenza aveva richiesto un trattamento. Trattamenti psicofarmacologici sono stati utilizzati dal $12 \%$ del campione, dal $19 \%$ con lieve o moderato disturbo mentale, e dal $37 \%$ con un disturbo mentale grave. Gli psicofarmaci più comunemente prescritti sono stati gli antidepressivi, seguiti dalle benzodiazepine; la psicoterapia è stata utilizzata dal $16 \%$. Tra coloro che avevano ricevuto una psicoterapia dopo il disastro, il 60\% aveva abbandonato la terapia. Quattordici per cento degli intervistati che non ha ottenuto il trattamento ha riferito che aveva bisogno di trattamento. In uno studio successivo, condotto tra persone con pre-esistenti disturbi mentali che avevano dichiarato di aver utilizzato i servizi di salute mentale nell'anno precedente l'uragano, più di un quinto aveva sperimentato una riduzione o una interruzione del trattamento dopo l'uragano Katrina (Wang et al. 2008).

Jones e colleghi (2009), per esempio, hanno dimostrato che le persone con gravi disturbi mentali sono un gruppo trascurato e vulnerabile in caso di emergenze complesse e hanno affermato che la protezione e l'assistenza delle persone con gravi disturbi mentali 
nelle emergenze complesse è una responsabilità umanitaria.

Per mitigare le catastrofi potenziali che aspettano l'umanità nel nuovo millennio, è urgentemente necessario un approccio evidence-based per la gestione dei disastri (Smith et al. 2009).

In questo numero di Epidemiology and Psychiatric Sciences, pubblichiamo tre Editoriali e uno Special Article su questo argomento. Il primo Editoriale è di Yuriko Suzuki e Yoshiharu Kim (2012) dal National Institute of Mental Health a Tokyo (Giappone). Gli autori analizzano le contromisure che sono state prese dopo il triplo disastro prodotto dal terremoto, dal maremoto e dall'incidente alla centrale elettrica nucleare avvenuto l'11 marzo 2011. Nelle prime fasi, un'iniziale risposta è stata messa in atto per assicurare la continuazione dei precedenti servizi psichiatrici e la fornitura dei farmaci necessari, così come il trattamento dei disturbi mentali acuti come panico, delirium o reazione da stress acuto. In base alle esperienze dei precedenti terremoti di Hanshin-Awaji nel 1995 e di Niigata nel 2004, Mental health team sono stati inviati nelle aree colpite. Questi team composti da psichiatri, infermieri, psicologi e/o altri operatori, molti dei quali inizialmente hanno viaggiato in fuoristrada, attrezzati per essere autosufficienti e indipendenti e per fornire farmaci e servizi per i pazienti psichiatrici ambulatoriali il cui trattamento era stato interrotto. La fornitura di informazioni è stata enormemente importante dopo il disastro per evitare confusione, non solo tra le persone colpite ma anche tra gli operatori dei servizi. Dopo sei mesi dal terremoto, i problemi in corso di valutazione sono quelli relativi alle reazioni prolungate, che vanno oltre il livello di una reazione normale, e forme più complesse di problemi legati all'evento che si sono aggiunte a quelle preesistenti.

Il secondo Editoriale, scritto da Massimo Casacchia, Rocco Pollice e Rita Roncone (2012) dell’Università de L'Aquila (Italia), riporta l'esperienza diretta degli Autori come superstiti di disastri e professionisti dei servizi psichiatrici a L'Aquila dopo il terremoto del 6 Aprile 2009. Il terremoto ha lasciato 66000 persone sfollate. Circa 44000 hanno trovato una sistemazione in campi attrezzati con tende vicino al loro luogo di residenza, e altre 20000 sono state ospitate negli hotel sul mare della costa adriatica abruzzese. Altri hanno trovato ospitalità presso amici e parenti in tutta Italia.

Dal loro osservatorio di operatori che lavorano direttamente sul campo, gli Autori ci spiegano i risultati degli studi condotti per valutare le conseguenze del disastro e le possibili strategie per affrontarli. Per esempio, tra i pazienti con una precedente diagnosi di schizofrenia che sono stati ricoverati nel reparto psichiatrico, il 15\% soddisfaceva i criteri del DSM-IV per il PTSD e ha mostrato una più grave sintomatologia positiva e un peggioramento statisticamente significativo della memoria di lavoro rispetto al sottogruppo di pazienti schizofrenici che non mostravano comorbidità con PTSD (Pollice et al. 2010).

L'Editoriale riporta, inoltre, informazioni sul Progetto 'Programma di Supporto psicosociale Emergenza Sisma' (SPES). Il progetto è stato realizzato in una tenda. E'stato approvato e finanziato a maggio 2009 dal Ministero della Salute italiano ed è ancora in corso. Il progetto comprende 3 aree principali di intervento: (1) la valutazione dell'impatto del terremoto sulla popolazione generale, (2) la collaborazione con i medici generici, al fine di migliorare le loro abilità nella identificazione e la gestione psicologica di eventi traumatici, (3) il supporto dei servizi di salute mentale della Regione, al fine di imparare specifici trattamenti EBM per il PTSD e di offrire una gamma più ampia di trattamenti EBM ai sopravvissuti.

Il terzo Editoriale è stato scritto da Lloyd I. Sederer (2012) e analizza le differenze tra le catastrofi naturali e quelle provocate dall'uomo. Sebbene non vi sia consenso di opinione nel mondo scientifico, sembra che le catastrofi provocate dall'uomo siano associate ad una disabilità clinica più grave e ad esiti peggiori dei disastri naturali. E'interessante notare che le catastrofi umane tendono ad avere un limite: non vengono e poi finiscono, come un uragano, un incendio o un'inondazione. La loro minaccia persiste, dato che chi ha provocato il disastro continua ad essere intorno a noi. Il nostro mondo diventa così imprevedibile e pericoloso. L'autore conclude che quando il disastro e il trauma sono provocati dall'uomo, il fondamento della fiducia negli altri e nella comunità è messo a dura prova e facilmente danneggiato.

In questo numero di Epidemiology and Psychiatric Sciences, pubblichiamo anche uno Special Article scritto da Ronald Kessler e colleghi (2012) su 'L'importanza dell'esposizione al trauma secondario per i disturbi mentali post-disastro'. Gli Autori riportano i risultati della WHO World Mental Health (WMH) Survey che mostrano chiaramente che una parte considerevole di persone nei paesi WMH sono stati esposti a catastrofi naturali, che una parte significativa di queste persone ha fatto esperienza di traumi secondari conseguenti al disastro (per esempio, la morte di una persona cara, distruzione di proprietà) e che la significativa associazione dell'esposizione al disastro con disturbi dell'umore e ansia è dovuta a questi fattori di stress secondario. L'importanza dei fattori di stress secondario complica il già difficile problema di salute pubblica di stimare i bisogni di trattamento dei disturbi mentali nel setting di un disastro.

I tre Editoriali e lo Special Article danno ai lettori EPS una visione globale delle sfide che devono affrontare 
gli studi epidemiologici in questo campo. I servizi di salute mentale dovrebbero essere pronti a far fronte alle conseguenze di disastri naturali e di disastri provocati dall'uomo e questa capacità dovrebbe essere supportata da evidenze scientifiche. Dobbiamo anche considerare che molto spesso i disastri naturali sono associati a catastrofiche conseguenze provocate dall'uomo a causa della deforestazione, della proliferazione non pianificata di costruzioni senza progetto, della comunicazione tardiva, della scarsa o nulla disponibilità di fondi per le strategie di prevenzione delle catastrofi. Per queste ragioni, i disastri naturali come quelli provocati dall'uomo possono produrre, tra gli altri traumi secondari, anche la mancanza di fiducia negli altri e nella comunità.

\section{References}

Casacchia M, Pollice R, Roncone R (2012). The narrative epidemiology of L'Aquila 2009 earthquake. Epidemiology and Psychiatric Sciences 21, 13-21.

Hogan DE, Burstein JL (2007). Basic perspectives on disasters. In Disaster Medicine (ed. DE Hogan and JL Burstein). pp. 1-11, Lippincott Williams \& Wilkins: Philadelphia, USA.

Jones L, Asare JB, El Masri M, Mohanraj A, Sherief H, van Ommeren M (2009). Severe mental disorders in complex emergencies. Lancet 374, 654-661.

Kessler RC, McLaughlin KA, Koenen KC, Petukhova M, Hill ED, The WHO World Mental Health Survey
Consortium (2012). The importance of secondary trauma exposure for post-disaster mental disorder. Epidemiology and Psychiatric Sciences 21, 35-45.

Pollice R, Bianchini V, Conti MC, Mazza M, Roncone R, Casacchia M (2010). Cognitive impairment and perceived stress in schizophrenic inpatients with Post-Traumatic Stress Disorder. European Journal of Inflammation 8, 211-219.

Rodriguez JJ, Kohn R (2008). Use of mental health services among disaster survivors. Current Opinion in Psychiatry 21, 370-378.

Sederer LI (2012). Are human made disasters different? Epidemiology and Psychiatric Sciences 21, 23-25.

Smith E, Wasiak J, Sen A, Archer F, Burkle FM Jr. (2009). Three decades of disasters: A review of disaster-specific literature from 1977-2009. Prehospital and Disaster Medicine 24, 306-311.

Suzuki Y, Kim Y (2012). The great Eastern Japan Earthquake in 2011; toward sustainable mental health care system. Epidemiology and Psychiatric Sciences 21, $7-11$.

Wang PS, Gruber MJ, Powers RE, Schoenbaum M, Speier AH, Wells KB, Kessler RC (2007). Mental health service use among hurricane Katrina survivors in the eight months after the disaster. Psychiatric Services 58, 1403-1411.

Wang PS, Gruber MJ, Powers RE, Schoenbaum M, Speier AH, Wells KB, Kessler RC (2008). Disruption of existing mental health treatments and failure to initiate new treatment after Hurricane Katrina. American Journal of Psychiatry 165, 34-41. 